\title{
PPAR $\gamma$-independent thiazolidinedione-mediated inhibition of NUR77 expression in vascular endothelial cells
}

\author{
Yunshan Hu ${ }^{1,2}$, Hong Bin Liu, ${ }^{1,2}$ Richard W Simpson ${ }^{2,3}$ and Anthony E Dear ${ }^{1,2}$ \\ ${ }^{1}$ Australian Centre for Blood Diseases and ${ }^{2}$ Eastern Clinical Research Unit, Biotechnology Division, Monash University, 6th Floor Burnett Tower, 89 Commercial \\ Road, Prahran, Melbourne, Victoria, Australia 3181 \\ ${ }^{3}$ Department of Diabetes and Endocrinology, Box Hill Hospital, 4th Floor Clive Ward Centre, Arnold Street, Box Hill, Melbourne, Victoria, Australia 3128 \\ (Correspondence should be addressed to A E Dear at Eastern Clinical Research Unit, Biotechnology Division, Australian Centre for Blood Diseases, \\ Monash University; Email: anthony.dear@med.monash.edu.au)
}

\begin{abstract}
The thiazolidinediones (TZDs) have been reported to reduce atherogenesis in preclinical models and atherosclerosis in clinical trials in pre-diabetic and diabetic patients. Although peroxisome proliferator-activated receptor $\gamma(\operatorname{PPAR} \gamma)-$ mediated effects on gene expression have been thought responsible for this effect, a complete understanding of the molecular mechanisms responsible remains to be fully elucidated. We have previously reported PPAR $\gamma$-independent modulation of NUR77 (also known as Nr4a1), an orphan nuclear receptor deemed important in the atherogenic process, in association with TZD-mediated inhibition of tumour necrosis factor $\alpha(\mathrm{TNF} \alpha)$ induction of plasminogen activator inhibitor type 1 expression. Here, we report NUR77 mRNA expression is increased in human vascular endothelial cells (HUVEC) stimulated by TNF $\alpha$ and that this effect is
\end{abstract}

inhibited by a TZD in a PPAR $\gamma$-independent manner. TZD treatment of HUVEC also inhibited the stimulatory effects of TNF $\alpha$ on NUR77 promoter activity, again in a PPAR $\gamma$ independent manner, confirming the transcriptional nature of this effect. TZD treatment also attenuated the binding of nuclear proteins to the nuclear factor kappa $\mathrm{B}(\mathrm{NF}-\mathrm{\kappa B})$ binding site of the NUR77 promoter in HUVEC in a PPAR $\gamma$ independent manner. In addition, TZD treatment also inhibited TNF $\alpha$-mediated induction of NF- $\kappa B 1 \mathrm{mRNA}$ expression. Our results suggest a potential PPAR $\gamma$-independent molecular mechanism for the anti-atherogenic effects of TZDs involving NF- $\kappa \mathrm{B}-$ mediated transcriptional inhibition of cytokine-mediated induction of the orphan nuclear receptor NUR77 in HUVEC.

Journal of Endocrinology (2011) 208, R1-R7

\section{Introduction}

Type 2 diabetes is characterised by accelerated atherosclerosis (Hobb 2006). Elevated tumour necrosis factor $\alpha(\mathrm{TNF} \alpha)$ levels and hyperglycaemia are implicated in diabetes-associated endothelial cell dysfunction and may be causal in premature atherosclerosis (Morigi et al. 1998, Liu et al. 2005, 2008, Norata et al. 2006, Kumar et al. 2007, Iwasaki et al. 2008).

Thiazolidinediones (TZDs) reduce insulin resistance, modify dyslipidaemia (Mimura et al. 1994), improve endothelial function and are thought to be protective against the development of atherosclerosis (Dormandy et al. 2005, Wöhrle et al. 2008). Some recent studies have suggested adverse cardiovascular effects of TZDs, in particular rosiglitazone (Home et al. 2007, Nissen \& Wolski 2010).

TZDs are activating synthetic ligands for the peroxisome proliferator activating receptor family of nuclear receptors (PPAR), particularly the PPAR $\gamma$ receptor, which acts to regulate gene transcription (Bar-Tana 2001). PPAR $\gamma$ is expressed most abundantly in adipose tissue, pancreatic $\beta$ cells, vascular endothelium and macrophages (Dubois et al. 2000, Willson et al. 2001). Some evidence suggests that the effects of TZDs are mediated independent of PPAR $\gamma$ with previous studies demonstrating PPAR $\gamma$-independent TZD-mediated inhibition of TNF $\boldsymbol{\alpha}$-stimulated plasminogen activator inhibitor type 1 (PAI-1, also known as SERPINE1) in human vascular EC cells (Liu et al. 2005).

The molecular mechanisms responsible for the PPAR $\gamma$ independent regulation of $P A I-1$ expression by TZDs remain to be fully elucidated although previous studies have demonstrated that the binding of the orphan nuclear receptor NUR77 (also known as Nr4a1) to its cis-acting response element in the proximal part of the $P A I-1$ promoter is crucial for upregulation of $P A I-1$ expression in vascular endothelial cells in response to TNF $\alpha$ (Gruber et al. 2003) and that TZDs modulate NUR77 expression in TNF-stimulated vascular endothelial cells in a PPAR $\gamma$-independent manner (Liu et al. 2005). 
NUR77, a member of orphan nuclear receptors NR4A subfamily, was initially identified as a growth factor-inducible gene (Milbrandt 1988). Orphan nuclear receptors are ligand independent (Baker et al. 2003, Wang et al. 2003) and consist of an $\mathrm{N}$-terminal transactivation domain, a central DNA-binding domain and a C-terminal 'ligand-binding' domain (He 2002). NR4A proteins bind to the NGFI-B response element (NBRE) sequence (AAAGGTCA) as monomers (Wilson et al. 1991) and to the palindromic NUR77 response element (NURRE) sequence (TGATATTTX $_{6}$ AAATGCCA) as homodimers (Philips et al. 1997) in responsive gene promoters.

NUR77 expression is increased in atherosclerotic vessels and co-localises with PAI-1 (Gruber et al. 2003). A dominantnegative form of NUR77 abolishes the effect of TNF $\alpha$ on PAI-1 expression (Gruber et al. 2003). Pei et al. (2005, 2006) demonstrated that NUR77 is expressed in macrophages within human atherosclerotic lesions and is highly induced by various inflammatory stimuli including $\mathrm{TNF} \boldsymbol{\alpha}$ via the nuclear factor kappa B (NF- $\kappa \mathrm{B})$ signalling pathway.

Our current studies aimed to determine the molecular mechanisms responsible for TZD-mediated regulation of NUR77 expression with a view to determining the potential molecular basis for the anti-atherogenic action of this class of agents.

\section{Materials and Methods}

\section{Cell culture}

Human vascular endothelial cells (HUVEC) were cultured to confluence at $37^{\circ} \mathrm{C}$ in gelatin-coated cell culture dishes in Media-199 with 20\% FCS and 6.0 mM glucose. Human embryo kidney cells (HEK 293) were cultured in DMEM medium with $10 \%$ FCS. Both cells were cultured with or without TNF $\alpha(10 \mathrm{ng} / \mathrm{ml}$; Promega) and with or without rosiglitazone $(10 \mu \mathrm{M})$ (kind gift from GlaxoSmithKline) $(10 \mu \mathrm{M})$ under serum-free conditions for designated times. The specific PPAR $\gamma$ antagonist SR202 dimethyl-(dimethoxyphosphinyl)-p-chlorobenzyl phosphate (Rieusset et al. 2002) was kindly provided by Ilex Onc (Geneva, Switzerland) and used at $100 \mu \mathrm{M}$ in experiments as indicated.

\section{Quantitative RT-PCR}

Total RNA was extracted from HUVEC using Trizol reagent (Invitrogen). An aliquot $(2 \mu \mathrm{g})$ of the total RNA was reverse transcribed in $20 \mu \mathrm{l}$ reaction mixture at $50{ }^{\circ} \mathrm{C}$ for $1 \mathrm{~h}$. cDNA was then amplified by real-time PCR using specific primers. Primers used to amplify human NUR77 were forward: 5'-GCT GCA GAA GTA CTC CACC-3', reverse: 5'-ACA GCA GCA CTG GGC TTA-3'. Primers used to amplify NF- $\kappa$ B1 were forward: $5^{\prime}$-CAG GAA GAT GTG GTG GAG GAT- ${ }^{\prime}$, reverse: ${ }^{\prime}$-TGT CTG GCT CCA CAG CCA GGT-3'.

\section{Transient transfection}

The $1.4 \mathrm{~kb}$ mouse NUR77 promoter was cloned into pGL3 basic luciferase reporter vector (kind gift from Prof. P Tontonoz, UCLA, USA). The mouse NUR77 promoter construct was transiently transfected into HEK 293 cells by using the calcium precipitate method in triplicate. Luciferase activity was normalised using the co-transfected $\beta$-galactosidase. The dominant-negative $\operatorname{PPAR} \gamma$ construct (Nugent et al. 2001) was the kind gift from Dr John Wentworth (Royal Melbourne Hospital, Melbourne, Australia).

Preparation of nuclear proteins and electrophoretic mobility shift assay

The nuclear proteins were extracted from HUVEC as described previously (Costa \& Medcalf 1996). Cells were added to $0.1 \mathrm{ml}$ NP40 lysis buffer $(0 \cdot 5 \%$ NP40, $10 \mathrm{mM}$ $\mathrm{NaCl}, 10 \mathrm{mM}$ Tris (pH 7.4), $3 \mathrm{mM} \mathrm{MgCl}_{2}, 5 \mathrm{mM}$ dithiothreitol (DTT) and $1 \mathrm{mM}$ phenylmethylsulphonyl fluoride (PMSF)) and incubated on ice for $10 \mathrm{~min}$. Then samples were briefly centrifuged and washed with $0.2 \mathrm{ml}$ NP40 buffer, and pellets were resuspended in $100 \mu \mathrm{l}$ of buffer C (420 mM NaCl, $20 \mathrm{mM}$ HEPES (pH 7.9), $1.5 \mathrm{mM}$ $\mathrm{MgCl}_{2}, 0 \cdot 2 \mathrm{mM}$ EDTA, 25\% glycerol and $5 \mathrm{mM}$ PMSF). After incubation on ice for $20 \mathrm{~min}$, samples were centrifuged for $20 \mathrm{~min}$ at $4{ }^{\circ} \mathrm{C}$ and the supernatants containing nuclear proteins were collected and stored at $-80^{\circ} \mathrm{C}$ for later use.

Oligonucleotides were labelled with $\left[\gamma-{ }^{32} \mathrm{P}\right] \mathrm{ATP}$ by using T4 polynucleotide kinase. After annealing with complementary strand, double-stranded oligonucleotides were gel purified as previously described (Costa \& Medcalf 1996). Electrophoretic mobility shift assays (EMSAs) were carried out by adding $4-10 \mu \mathrm{g}$ nuclear proteins to $4 \mu \mathrm{l}$ Osborne buffer D (20 mM HEPES (pH 7.9), 2.0 mM $\mathrm{MgCl}_{2}, 0 \cdot 2 \mathrm{mM}$ EDTA, $20 \%$ glycerol, $5 \mathrm{mM}$ DTT, $5 \mathrm{mM}$ PMSF and $50 \mathrm{mM} \mathrm{KCl}$; Osborn et al. 1989) and incubating at $4{ }^{\circ} \mathrm{C}$ for $15 \mathrm{~min}$ with $1 \mu \mathrm{l}$ poly[d(1-C)] and $3 \mu \mathrm{l}$ SMK buffer ( $12 \mathrm{mM}$ spermidine, $12 \mathrm{mM} \mathrm{MgCl}_{2}$ and $200 \mathrm{mM} \mathrm{KCl}$. In all, $4 \mu \mathrm{l}{ }^{32} \mathrm{P}$-labelled probe $(100$ c.p.m.) diluted in Osborne buffer $\mathrm{D}$ were then added and the mixture was incubated on ice for further $10 \mathrm{~min}$ before being applied to a native 5\% polyacrylamide gel (Osborn et al. 1989). For competition experiments, nuclear proteins were incubated with $200 \mathrm{ng}$ unlabelled oligomers of either identical or unrelated sequence for $15 \mathrm{~min}$ prior to the addition of the probe. After electrophoresis, gels were fixed and dried, then autoradiographed over one or two nights at $-70{ }^{\circ} \mathrm{C}$ with an intensifying screen. The sequence of the labelled NF- $\kappa \mathrm{B}$ oligonucleotide was 5'-GCG-GGC-TGT-TCC-TCACTC-CA-3', and sequence of the non-specific, unrelated competitor was 5'-CTT-GAT-CCA-TCC-ACT-GCC$\mathrm{GG}-3^{\prime}$. All experiments were performed three times. 


\section{Statistical analysis}

The effects of the agents on NUR77 promoter activity were assessed by ANOVA. Data were expressed as mean \pm S.E.M. and $P<0 \cdot 05$ was considered statistically significant.

\section{Results}

TZD-mediated regulation of NUR77 $m R N A$ expression

Previous studies have shown that in HUVEC, expression of NUR77 mRNA is highly inducible by TNF $\alpha$ (Gruber et al. 2003) although the effects of TZDs on TNF $\alpha$-mediated induction of NUR77 expression in this cell type are unknown. HUVECs were treated with TNF $\alpha$ and rosiglitazone for 1, 2 and $4 \mathrm{~h}$. Real-time quantitative PCR (qPCR) was used to identify NUR77 mRNA expression in HUVEC cells. Time-course experiments demonstrated that expression of NUR77 mRNA was significantly induced by TNF $\alpha$ as early as $1 \mathrm{~h}$ by up to 18 -fold over untreated control cells, and then reduced to 2 -fold over untreated cells at $4 \mathrm{~h}$ treatment (Fig. 1). Co-treatment with rosiglitazone of TNF $\alpha$-treated HUVEC cells resulted in a profound inhibition of $\mathrm{TNF} \alpha$ induction of NUR77 mRNA expression to approximately fivefold at $1 \mathrm{~h}$ (Fig. 1). The inhibitory effect of rosiglitazone on TNF $\alpha$-mediated induction of NUR77 expression was demonstrated to be independent of PPAR $\gamma$ activity as addition of the specific PPAR $\gamma$ inhibitor SR202 (Rieusset et al. 2002) did not affect the inhibitory action of rosiglitazone on TNF $\alpha$-mediated induction of NUR 77 mRNA expression at $1 \mathrm{~h}$ (Fig. 2).

\section{TZD-mediated regulation of NUR77 promoter activity}

The mouse $1.4 \mathrm{~kb}$ NUR77 promoter was used to examine the effects of rosiglitazone on regulation of TNF $\alpha$ induction of NUR77 promoter activity. TNF $\alpha$ stimulation $(10 \mathrm{ng} / \mathrm{ml})$

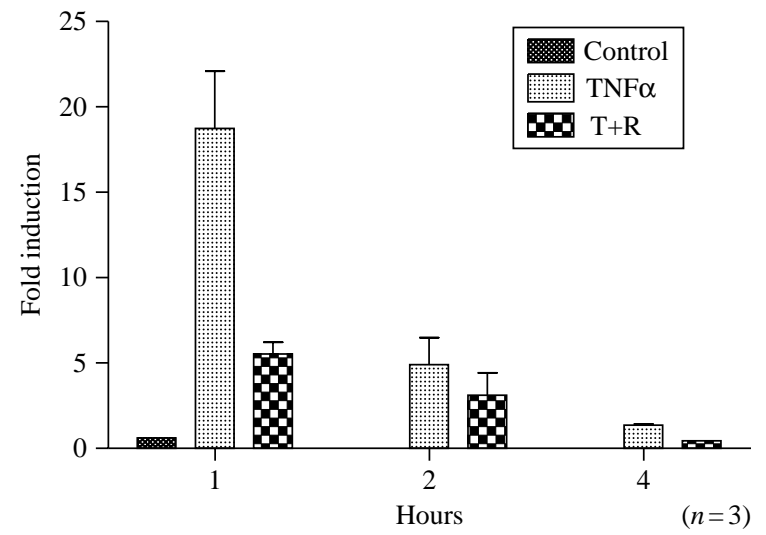

Figure 1 Time course of NUR77 mRNA expression. HUVEC cells were treated with TNF $\alpha(10 \mathrm{ng} / \mathrm{ml})$ with or without rosiglitazone $(10 \mu \mathrm{M})$ for the indicated times. T, TNF $\alpha ; \mathrm{R}$, rosiglitazone; T+R, TNF $\alpha+$ rosiglitazone $(n=3)$.

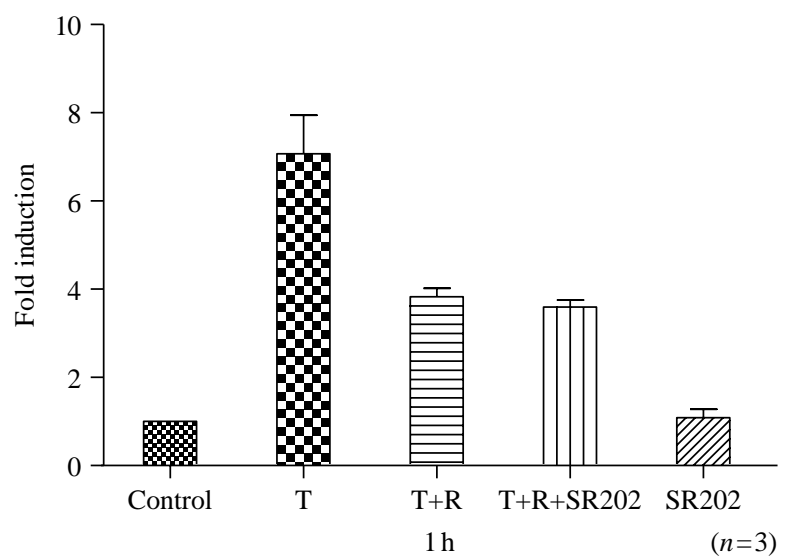

Figure 2 Effect of SR202 on $1 \mathrm{~h}$ TNF $\alpha$-induced NUR77 mRNA expression. Control, untreated; T, TNF $\alpha(10 \mathrm{ng} / \mathrm{ml}) ; \mathrm{R}$, rosiglitazone $(10 \mu \mathrm{M}) ; \mathrm{T}+\mathrm{R}, \mathrm{TNF} \alpha+$ rosiglitazone; SR202, treated with $100 \mu \mathrm{M}$ SR202 $(n=3)$.

induced NUR77 promoter activity within $1 \mathrm{~h}$ and continued for up to $3 \mathrm{~h}$ (Fig. 3a). Rosiglitazone had no significant effect on TNF $\alpha$-induced NUR77 promoter activity within $3 \mathrm{~h}$ (Fig. 3a) although a trend to inhibition was noted at the later time point (e.g. 3 h; Fig. 3a). Specific treatment with TNF $\alpha$ for $4 \mathrm{~h}$ resulted in significant upregulation of NUR77 promoter activity and a significant inhibitory effect of rosiglitazone on TNF $\alpha$-induced NUR77 promoter activity at $4 \mathrm{~h}$ (Fig. 3b). Treatment of transfected cells with the specific PPAR $\gamma$ inhibitor SR202 had no effect on suppression of TNF $\alpha$ stimulated NUR77 promoter activity by rosiglitazone (Fig. 3b), suggesting that this transcriptional effect was PPAR $\gamma$ independent. Co-transfection of a PPAR $\gamma$ dominant-negative construct into the cells transfected with the NUR77 promoter construct also had no effect on rosiglitazone-mediated suppression of $\mathrm{TNF} \alpha$-stimulated NUR77 promoter activity (Fig. 4), confirming the PPAR $\gamma$-independent nature of this effect.

Nuclear protein binding to the $N F-\kappa B$-binding site in the NUR77 promoter

The human and mouse Nur77 promoters share highly conserved binding sites for NF- $\mathrm{NB}$ and AP-1 transcription factors (Pei et al. 2005). To define the molecular mechanism of TZD-mediated inhibition of NUR77 expression, we performed EMSAs using the NF- $\kappa \mathrm{B}$-binding sites within the NUR77 promoter region (nt -1151 to -1170 ). EMSA results demonstrate that ${ }^{32} \mathrm{P}$-labelled oligonucleotides harbouring the NF- $\mathrm{BB}$-binding site within the NUR 77 promoter specifically bind nuclear proteins from HUVEC cells (Fig. 5). The intensity of the protein/DNA complex increased with TNF $\alpha$ treatment, which was subsequently downregulated by the concomitant treatment with rosiglitazone (Fig. 5). Co-treatment with the specific PPAR $\gamma$ inhibitor SR202 
had minimal effect on rosiglitazone attenuation of specific nuclear protein binding in TNF $\boldsymbol{\alpha}$-stimulated cells, suggesting that this effect is independent of PPAR $\gamma$ activity (Fig. 5).

\section{TZD-mediated modulation of NF- $\kappa \mathrm{B} 1 \mathrm{mRN} A$ expression}

Having identified TZD-mediated attenuation of nuclear protein binding to the NF- $\kappa \mathrm{B}$-binding site in the NUR77 promoter, we were interested in determining the effect of TZDs on the expression of NF- $\kappa B 1 \mathrm{mRNA}$ as a possible molecular mechanism for this observation. Previous studies have demonstrated that the induction of NUR77 expression by lipopolysaccharide (LPS) was severely attenuated in the fibroblasts lacking the three NF- $\kappa B$ subunits, NF- $\kappa B 1$, C-REL and REL A (Pei et al. 2005).

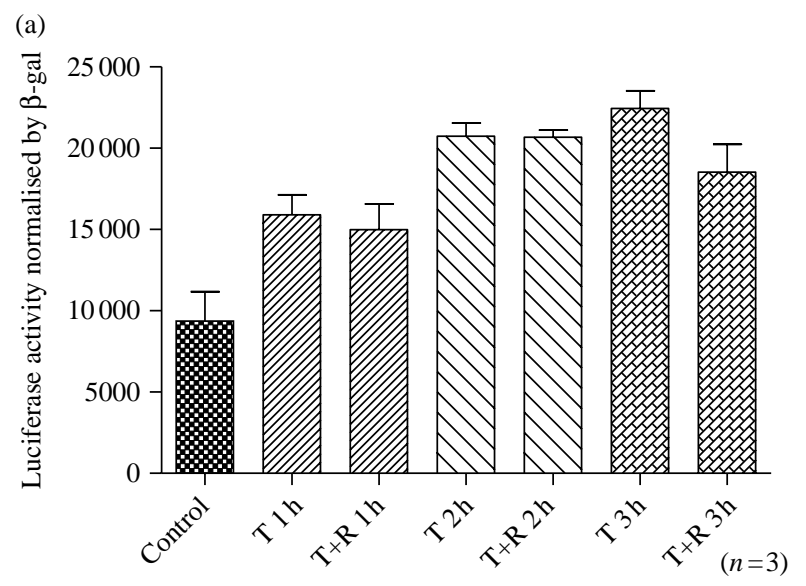

(b)

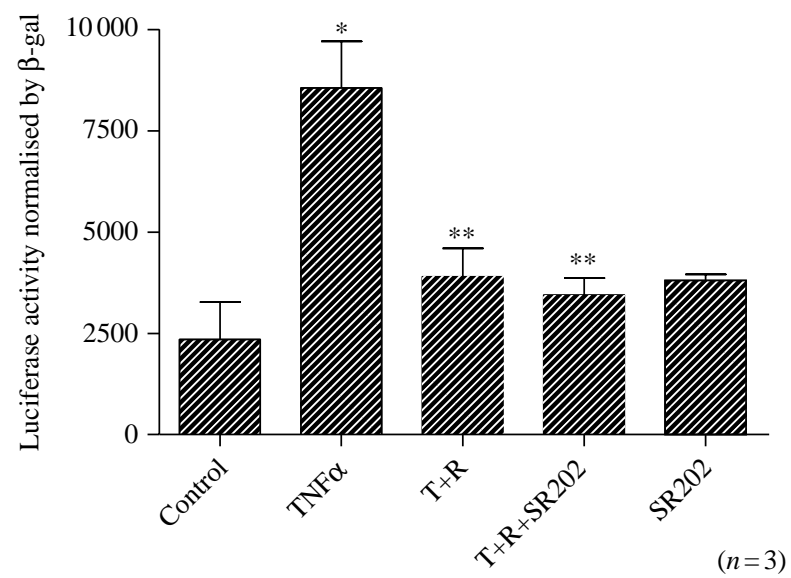

Figure 3 (a) Time course of effect of rosiglitazone treatment on TNF $\alpha$-stimulated NUR77 promoter activity as assessed by luciferase activity normalised by $\beta$-galactosidase activity in transfected HEK 293 cells. Control, untreated; T, TNF $\alpha(10 \mathrm{ng} / \mathrm{ml}) ; \mathrm{R}$, rosiglitazone $(10 \mu \mathrm{M})$; T $+\mathrm{R}, \mathrm{TNF} \alpha+$ rosiglitazone $(n=3)$. (b) Effect of rosiglitazone and SR202 treatment on mouse Nur 77 promoter construct for $4 \mathrm{~h}$. Control, untreated; T, TNF $\alpha(10 \mathrm{ng} / \mathrm{ml}) ; \mathrm{R}$, rosiglitazone $(10 \mu \mathrm{M}) ; \mathrm{T}+\mathrm{R}, \mathrm{TNF} \alpha+$ rosiglitazone; SR202, treated with $100 \mu \mathrm{M}$ SR202 $(n=3),{ }^{*} P<0 \cdot 05$, T versus control $\left({ }^{*} P<0 \cdot 05\right) ;{ }^{*} P<0 \cdot 05$, $T$ versus $T+R$ and $T+R+S R 202$.

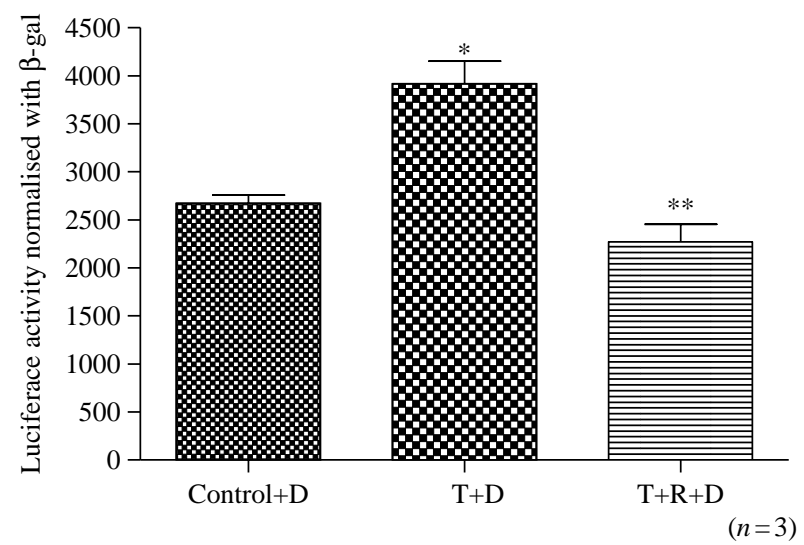

Figure 4 Effect of rosiglitazone and/or TNF $\alpha$ treatment for $4 \mathrm{~h}$ on NUR77 promoter activity in HEK 293 cells co-transfected with a dominant-negative PPAR $\gamma$ mutant construct. Control, untreated; $\mathrm{T}, \mathrm{TNF} \alpha(10 \mathrm{ng} / \mathrm{ml}) ; \mathrm{R}$, rosiglitazone $(10 \mu \mathrm{M}) ; \mathrm{T}+\mathrm{R}, \mathrm{TNF} \alpha+$ rosiglitazone; $\mathrm{D}$, dominant-negative PPAR $\gamma$ mutant construct $(n=3),{ }^{*} P<0 \cdot 05$, T versus control; ${ }^{* *} P<0 \cdot 05, \mathrm{~T}$ versus $\mathrm{T}+\mathrm{R}$.

Real-time qPCR was used to identify NF- $K B 1$ mRNA expression in HUVEC cells. Experiments demonstrated that expression of $N F-\kappa B$ mRNA was significantly induced by $\mathrm{TNF} \alpha$ at $1 \mathrm{~h}$ by up to fourfold over untreated control cells, and then significantly reduced to twofold over untreated cells by co-treatment with rosiglitazone of TNF $\alpha$-treated HUVEC cells (Fig. 6).

\section{Discussion}

Upregulation of PAI-1 is recognised as a marker of endothelial cell dysfunction (Devaraj et al. 2003) and is found in patients with metabolic syndrome (MS) and diabetes. Previous studies have demonstrated inhibition of MS and atherosclerosis in PAI-1-deficient mice (Eitzman et al. 2000, Mao et al. 2004), and therefore inhibition of TNF $\alpha$-induced endothelial cell $P A I-1$ expression may reduce the risk of atherosclerosis in diabetes and in patients with MS.

Expression of the orphan nuclear receptor NUR77 is increased in atherosclerotic vessels and co-localises with PAI-1 (Gruber et al. 2003). Previous studies have demonstrated that NUR77 binding to the proximal part of the PAI-1 promoter is crucial for upregulation of PAI-1 expression in vascular endothelial cells in response to TNF $\alpha$ stimulation (Gruber et al. 2003). Our previous results have demonstrated that rosiglitazone attenuates the TNF $\alpha$-mediated increase in NUR77 expression and binding of nuclear proteins to the PAI-1 NBRE-binding site in a PPAR $\gamma$-independent manner (Liu et al. 2005). We have been interested in the molecular mechanism responsible for PPAR $\gamma$-independent regulation of NUR77 expression by TZDs in vascular endothelial cells.

Our current studies demonstrate that rosiglitazone significantly inhibited TNF $\boldsymbol{\alpha}$-induced NUR77 mRNA expression after $1 \mathrm{~h}$ treatment (Fig. 1) and that this effect was PPAR $\gamma$ 
independent (Fig. 2). Rosiglitazone treatment also reduced TNF $\alpha$-stimulated NUR77 promoter activity significantly at $4 \mathrm{~h}$ (Fig. 3), again in a PPAR $\gamma$-independent manner (Figs 3 and 4), suggesting the effect of rosiglitazone on NUR77 mRNA expression was transcriptional. The difference in the timing of the effects of rosiglitazone on NUR77 mRNA expression and promoter activity ( $1 \mathrm{~h}$ in the case of NUR77 mRNA and $4 \mathrm{~h}$ for inhibition of NUR77 promoter activity) is likely to reflect the translational component of the transfection assay with translation of luciferase protein from mRNA.

The NUR77 gene promoter has no classical PPRE response element, and as our observations suggested a

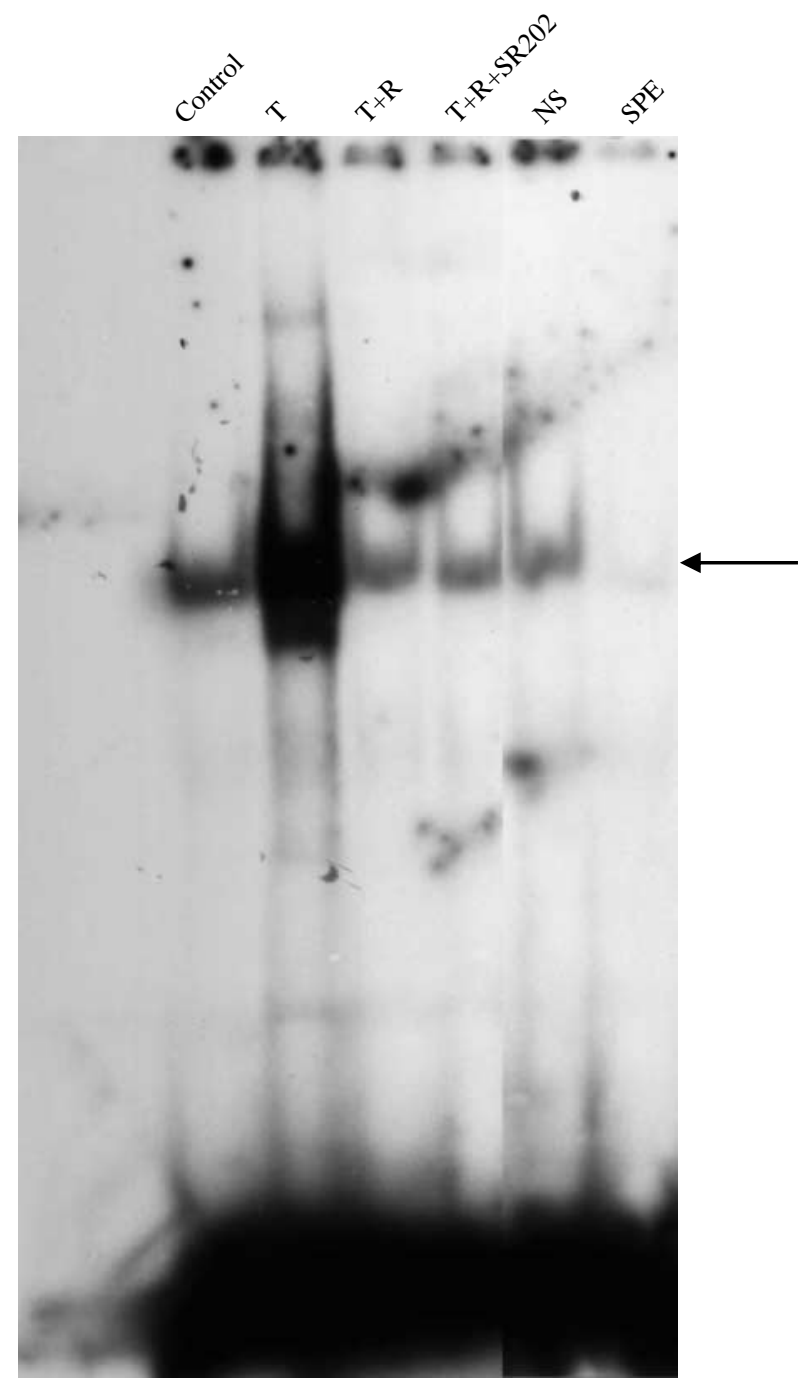

Figure 5 Effect of $\mathrm{TNF} \alpha$, rosiglitazone and SR202 on binding of nuclear proteins to the NF-KB-binding site in NUR77 promoter in HUVEC cells. Control, untreated; T, TNF $\alpha(10 \mathrm{ng} / \mathrm{ml}) ; \mathrm{T}+\mathrm{R}$, TNF $\alpha+$ rosiglitazone $(10 \mu \mathrm{M}) ; \mathrm{T}+\mathrm{R}+\mathrm{SR} 202, \mathrm{~T}+\mathrm{R}+$ treated with $100 \mu \mathrm{M}$ SR202; NS, non-specific (unrelated) oligonucleotide; SPE, identical oligonucleotide $(n=3)$. Arrow indicates specific binding.

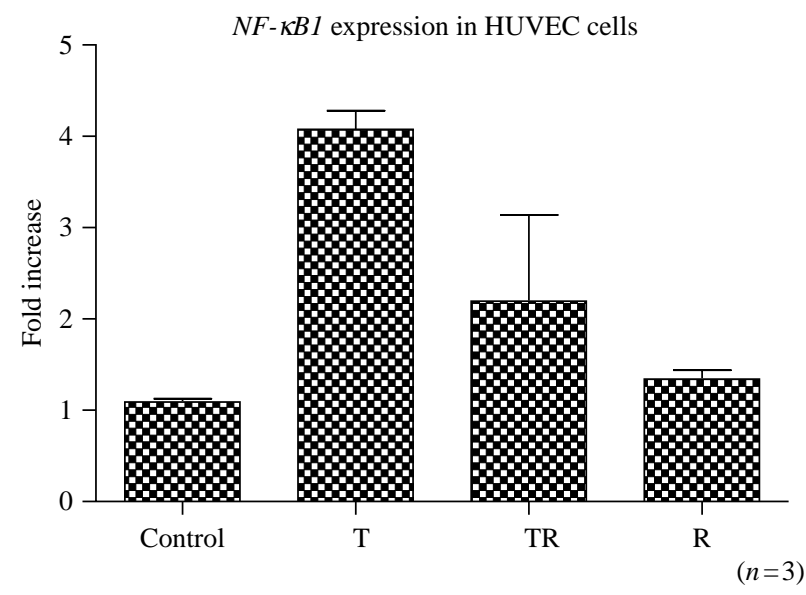

Figure 6 Effect of TNF $\alpha$ and/or rosiglitazone for $1 \mathrm{~h}$ on NF-KB mRNA expression in HUVEC cells. Control, untreated; T, TNF $\alpha(10 \mathrm{ng} / \mathrm{ml})$; $\mathrm{R}$, rosiglitazone $(10 \mu \mathrm{M}) ; \mathrm{T}+\mathrm{R}, \mathrm{TNF} \alpha+$ rosiglitazone $(n=3)$.

PPAR $\gamma$-independent effect of rosiglitazone on NUR77 promoter activity, we were interested in identifying the molecular mechanism responsible for this effect.

Previously Pei et al. (2005) have suggested a role for NUR77 in atherogenesis with the rapid induction of NUR77 expression by inflammatory stimuli, such as LPS, a process requiring the action of NF- $\mathrm{KB}$ proteins on the NUR77 promoter. Our EMSA results demonstrated that TNF $\alpha$ treatment increased the binding of nuclear proteins from HUVEC cells to the NF- $\kappa B$-binding site of NUR77 promoter (Fig. 5). Rosiglitazone treatment attenuated the TNF $\alpha$ mediated increase in binding of nuclear proteins to this binding site. The specific PPAR $\gamma$ inhibitor SR202 failed to inhibit this effect significantly (Fig. 5). In addition, rosiglitazone also inhibited TNF $\alpha$-mediated induction of NF- $\kappa B 1$ mRNA expression, offering a possible molecular explanation for the effects of rosiglitazone on NUR77 expression (Fig. 6).

Taken together, rosiglitazone-mediated inhibition of TNF $\boldsymbol{\alpha}$-induced NUR77 mRNA expression correlates with inhibition of NUR77 promoter activity, binding of nuclear proteins from HUVEC cells to the NUR77 NF- $\kappa B$-binding site and reduced NF- $\kappa B 1 \mathrm{mRNA}$ expression, independent of inducible PPAR $\gamma$ activation. These findings suggest a novel PPAR $\gamma$-independent molecular mechanism responsible for TZD modulation of NUR77 expression, which may in turn be responsible for modulation of PAI-1.

The identification of a potentially novel $\operatorname{PPAR} \gamma$-independent molecular mechanism responsible for TZD modulation of NUR77 expression may in part explain the identified effects of TZDs on inhibition of PAI-1 expression and subsequent atheroprotection of TZDs in in vivo models and clinical studies. However, and perhaps more importantly, these observations may afford the potential for design of novel 'PPAR $\gamma$-independent' atheroprotective agents in the future. 


\section{Declaration of interest}

The authors declare that there is no conflict of interest that could be perceived as prejudicing the impartiality of the research reported.

\section{Funding}

This research did not receive any specific grant from any funding agency in the public, commercial or not-for-profit sector.

\section{References}

Baker KD, Shewchuk LM, Kozlova T, Makishima M, Hassell A, Wisely B, Caravella JA, Lambert MH, Reinking JL, Krause H et al. 2003 The Drosophila orphan nuclear receptor DHR38 mediates an atypical ecdysteroid signaling pathway. Cell 113 731-742. (doi:10.1016/S00928674(03)00420-3)

Bar-Tana J 2001 Peroxisome proliferator-activated receptor $\gamma$ (PPAR) activation and its consequences in humans. Toxicology Letters 120 9-19. (doi:10.1016/S0378-4274(01)00302-2)

Costa M \& Medcalf RL 1996 Differential binding of cAMP-responsiveelement (CRE)-binding protein-1 and activating transcription factor-2 to a CRE-like element in the human tissue-type plasminogen activator (t-PA) gene promoter correlates with opposite regulation of t-PA by phorbol ester in HT-1080 and HeLa cells. European Journal of Biochemistry 237 532-538. (doi:10.1111/j.1432-1033.1996.00532.x)

Devaraj S, Xu DY \& Jialal I 2003 C-reactive protein increases plasminogen activator inhibitor-1 expression and activity in human aortic endothelial cells: implications for the metabolic syndrome and atherothrombosis. Circulation 107 398-404. (doi:10.1161/01.CIR. 0000052617.91920.FD)

Dormandy JA, Charbonnel B, Eckland DJ, Erdmann E, Massi-Benedetti M, Moules IK, Skene AM, Tan MH, Lefêbvre PJ, Murray GD et al. 2005 Secondary prevention of macrovascular events in patients with type 2 diabetes in the PROactive Study (PROspective pioglitAzone Clinical Trial In macroVascular Events): a randomised controlled trial. Lancet 366 1279-1289. (doi:10.1016/S0140-6736(05)67528-9)

Dubois M, Pattou F, Kerr-Conte J, Gmyr V, Vandewalle B, Desreumaux P, Auwerx J, Schoonjans K \& Lefebvre J 2000 Expression of peroxisome proliferator-activated receptor $\gamma$ (PPAR $\gamma$ ) in normal human pancreatic islet cells. Diabetologia 43 1165-1169. (doi:10.1007/s001250051508)

Eitzman DT, Westrick RJ, Xu Z, Tyson J \& Ginsburg D 2000 Plasminogen activator inhibitor-1 deficiency protects against atherosclerosis progression in the mouse carotid artery. Blood 96 4212-4215.

Gruber F, Hufnagl P, Hofer-Warbinek R, Schmid JA, Breuss JM, Huber-Beckmann R, Lucerna M, Papac N, Harant H, Lindley I et al. 2003 Direct binding of Nur77/NAK-1 to the plasminogen activator inhibitor 1 (PAI-1) promoter regulates TNF $\alpha$-induced PAI-1 expression. Blood 101 3042-3248. (doi:10.1182/blood-2002-07-2331)

He YW 2002 Orphan nuclear receptors in T lymphocyte development. Journal of Leukocyte Biology 72 440-446 (Review).

Hobb FD 2006 Type-2 diabetes mellitus related cardiovascular risk: new options for interventions to reduce risk and treatment goals. Atherosclerosis 7 $29-32$.

Home PD, Pocock SJ, Beck-Nielsen H, Gomis R, Hanefeld M, Jones NP, Komajda M, McMurray JJ \& RECORD Study Group 2007 Rosiglitazone evaluated for cardiovascular outcomes - an interim analysis. New England Journal of Medicine 357 28-38. (doi:10.1056/ NEJMoa073394)

Iwasaki K, Matsumoto T, Aono H, Furukawa H \& Samukawa M 2008 Prevalence of subclinical atherosclerosis in asymptomatic diabetic patients by 64-slice computed tomography. Coronary Artery Disease 19 195-201. (doi:10.1097/MCA.0b013e3282f3fbef)
Kumar S, Singh BK, Pandey AK, Kumar A, Sharma SK, Raj HG, Prasad AK, Van der Eycken E, Parmar VS \& Ghosh B 2007 A chromone analog inhibits TNF- $\alpha$ induced expression of cell adhesion molecules on human endothelial cells via blocking NF- $\kappa \mathrm{B}$ activation. Bioorganic and Medicinal Chemistry 15 2952-2962. (doi:10.1016/j.bmc. 2007.02.004)

Liu HB, Hu YS, Medcalf RL, Simpson RW \& Dear AE 2005 Thiazolidinediones inhibit TNF $\alpha$ induction of PAI-1 independent of PPAR $\gamma$ activation. Biochemical and Biophysical Research Communications 334 30-37. (doi:10.1016/j.bbrc.2005.06.055)

Liu HB, Hu Y, Simpson RW \& Dear AE 2008 Glucagon-like peptide-1 attenuates tumour necrosis factor- $\alpha$-mediated induction of plasmogen activator inhibitor-1 expression. Journal of Endocrinology 196 57-65. (doi:10.1677/JOE-07-0387)

Mao LJ, Mao SL, Taylor KL, Kanjanabuch T, Guan Y, Zhang Y, Brown NJ, Swift LL, McGuinness OP, Wasserman DH et al. 2004 Prevention of obesity and insulin resistance in mice lacking plasminogen activator inhibitor 1. Diabetes 53 336-346. (doi:10.2337/ diabetes.53.2.336)

Milbrandt J 1988 Nerve growth factor induces a gene homologous to the glucocorticoid receptor gene. Neuron 1 183-188. (doi:10.1016/ 0896-6273(88)90138-9)

Mimura K, Umeda F, Hiramatsu S, Taniguchi S, Ono Y, Nakashima N, Kobayashi K, Masakado M, Sako Y \& Nawata H 1994 Effects of a new oral hypoglycaemic agent (CS-045) on metabolic abnormalities and insulin resistance in type 2 diabetes. Diabetic Medicine 11 685-691. (doi:10.1111/j.1464-5491.1994.tb00333.x)

Morigi M, Zoja C, Colleoni S, Angioletti S, Imberti B, Remuzzi A \& Remuzzi G 1998 Xenogeneic human serum promotes leukocyte adhesion to porcine endothelium under flow conditions, possibly through the activation of the transcription factor NF- $\kappa$ B. Xenotransplantation 5 57-60. (doi:10.1111/j.1399-3089.1998.tb00009.x)

Nissen SE \& Wolski K 2010 Rosiglitazone revisited: an updated meta-analysis of risk for myocardial infarction and cardiovascular mortality. Archives of Internal Medicine (In Press).

Norata GD, Grigore L, Raselli S, Seccomandi PM, Hamsten A, Maggi FM, Eriksson P \& Catapano AL 2006 Triglyceride-rich lipoproteins from hypertriglyceridemic subjects induce a pro-inflammatory response in the endothelium: molecular mechanisms and gene expression studies. Journal of Molecular and Cellular Cardiology 40 484-494. (doi:10.1016/j.yjmcc.2006. 01.022)

Nugent C, Prins JB, Whitehead JP, Savage D, Wentworth JM, Chatterjee VK \& O'Rahilly S 2001 Potentiation of glucose uptake in 3T3-L1 adipocytes by PPAR $\gamma$ agonists is maintained in cells expressing a PPAR $\gamma$ dominantnegative mutant: evidence for selectivity in the downstream responses to PPAR $\gamma$ activation. Molecular Endocrinology 15 1729-1738. (doi:10.1210/ me.15.10.1729)

Osborn L, Kunkel S \& Nabel GJ 1989 Tumor necrosis factor $\boldsymbol{\alpha}$ and interleukin 1 stimulate the human immunodeficiency virus enhancer by activation of the nuclear factor $\kappa B$. PNAS 86 2336-2340. (doi:10.1073/ pnas.86.7.2336)

Pei L, Castrillo A, Chen M, Hoffmann A \& Tontonoz P 2005 Induction of NR4A orphan nuclear receptor expression in macrophages in response to inflammatory stimuli. Journal of Biological Chemistry 280 29256-29262. (doi:10.1074/jbc.M502606200)

Pei L, Castrillo A \& Tontonoz P 2006 Regulation of macrophage inflammatory gene expression by the orphan nuclear receptor Nur77. Molecular Endocrinology 20 786-794. (doi:10.1210/me.2005-0331)

Philips A, Lesage S, Gingras R, Maira MH, Gauthier Y, Hugo P \& Drouin J 1997 Novel dimeric Nur77 signaling mechanism in endocrine and lymphoid cells. Molecular and Cellular Biology 17 5946-5951.

Rieusset J, Touri F, Michalik L, Escher P, Desvergne B, Niesor E \& Wahli W 2002 A new selective peroxisome proliferator-activated receptor $\gamma$ antagonist with antiobesity and antidiabetic activity. Molecular Endocrinology 16 2628-2644. (doi:10.1210/me.2002-0036) 
Wang Z, Benoit G, Liu J, Prasad S, Aarnisalo P, Liu X, Xu H, Walker NP \& Perlmann T 2003 Structure and function of Nurr1 identifies a class of ligand-independent nuclear receptors. Nature 423 555-560. (doi:10.1038/ nature01645)

Wilson TE, Fahrner TJ, Johnston M \& Milbrandt J 1991 Identification of the DNA binding site for NGFI-B by genetic selection in yeast. Science $\mathbf{2 5 2}$ 1296-1300. (doi:10.1126/science.1925541)

Willson TM, Lambert MH \& Kliewer SA 2001 Peroxisome proliferator-activated receptor $\gamma$ and metabolic disease. Annual Review of Biochemistry 70 341-367 (Review). (doi:10.1146/annurev. biochem.70.1.341)
Wöhrle J, Marx N, Koenig W, Hombach V, Kestler HA, Höher M \& Nusser T 2008 Impact of pioglitazone on coronary endothelial function in nondiabetic patients with coronary artery disease. Clinical Research in Cardiology 97 726-733. (doi:10.1007/s00392-008-0663-8)

Received in final form 11 October 2010

Accepted 19 October 2010

Made available online as an Accepted Preprint 19 October 2010 